\section{An analysis of corruption: the American continent versus Romania}

Silviu DUȚULESCU,

E-mail: silviudemetrius@yahoo.com

Ileana NIŞULESCU-ASHRAFZADEH, E-mail: ileana.nisulescu@cig.ase.ro, The Bucharest University of Economic Studies, Bucharest, Romania

\section{Albstract}

Corruption has become one of the most vicious mass phenomena, affecting, in most cases, the general wealth of the population. The paper closely surveys a set of measurable variables which have a very high impact over the dimensions of corruption as a phenomenon. Two of the aforementioned variables are part of a bureaucratic component, specific to the public system the number of taxes, duties and contributions that an economic entity has to pay for the right to conduct business on the territory of a state, and the amount of time assigned for the payment of the duties for a year's interval. The variable, generally called the taxation level, assumes an economic perspective over the phenomenon of corruption, which may be encouraged or, on the contrary, inhibited by the government's fiscal strategy. The last component, called Human Development Index (HDI), assumes a social perspective over corruption, surveying the people's behavior, which is also able to amplify or decrease the dimensions of corruption as a phenomenon. The whole scientific attempt is synthesized in the form of a corruption map, based on the estimated spread of the phenomenon for each surveyed country.

Keywords: Corruption, Country charts, Corruption map, American Continent

JEL Classification: C31, D11, 011

To cite this article:

Duțulescu, S. and Nişulescu-Ashrafzadeh, I. (2016), An analysis of corruption: the American continent versus Romania, Audit Financiar, vol. XIV, no. 4(136)/2016, pp. 436-444, DOI: 10.20869/ AUDITF/2016/136/436.

Permanent link to this document: http://dx.doi.org/10.20869/AUDITF/2016/136/436. 


\section{Introduction}

Corruption is a mass phenomenon having multiple valences. As seen from an economic perspective, corruption may be considered as a threat to the democratic regimes, as it allows violation of social rules, generating social inequities and discrediting governmental institutions, which finally has negative effects over the economic development of a country (Straupenhurst, Ulrich and Strohal, 2006).

Generalized corruption is considered to happen when the general social services, which should be available for the population, are controlled by a small group of people which are intentionally using them for their own personal benefits (Jensen, Li and Rahman, 2010). A very good proof of the destructive potential corruption has when out of control may be found in a LatinAmerican country, namely Peru, which owns one of the largest gold mines in the world, Yanacocha, but is not able to capitalize this potential for the general wealth of the own population, which, in large majority, lives in poverty. Another proof for the destructive potential of corruption may be found in Russia. According to the Transparency International's report in 2010, Russia was the most corrupt country in $\mathrm{G} 20$, being at par with countries like Papua - New Guinea, Congo-Brazzaville or Kenya. From a social perspective, the corruption may be correlated with the power abuse allowed by a public office, for personal or group interest, so as to obtain financial, status-related or image-related advantages. The corruption phenomenon, exactly as a computer hacker, aims the vulnerable areas of the public system, and then illegally exploits them for personal benefits (Raicu, 2010).

A faulty legal system which allows for social inequities and does not require total transparency, may become an aggravating factor for the development of corruption. Corruption flourishes in the absence of transparency, while responsibility and transparency are basic prerequisites for its prevention (Pană and Nişulescu, 2013).

Uslaner (2008) finds that countries having authoritarian regimes also have an increased risk for the development of corruption, when compared to democratic states. Morris (2009) has developed some detailed analyses in this area, surveying the political elites' possibilities to reform and implement measures for the significant decrease of corruption, both in democratic and totalitarian regimes. In order for the corruption to exist, it should act and be functional on two different directions. The first one is the corrupting power, the second is the corruptible power. The tighter the relation between the two, the higher the corruption level. Unfortunately, during the last years, in Romanian top offices were promoted a lot of persons missing a proper moral conduit and showing an open support for the political elites shaping the destiny of the people (Voicu, 2013). The twodirectional approach of the corruption as a phenomenon can also be found in the European Commission's report regarding the directives for combating corruption in the private sector. Thereby, the phenomenon of corruption is divided into active corruption, designed to provide economic benefits for the preferential settlement of some issues, while passive corruption involves the passive acceptance or even the request of such economic benefits (Maxim, 2013). The government may be able to limit corruption at the level of companies, by means of an equal treatment for all companies, without size-based discrimination; as an economic entity, in the absence of sales value, profit or employees' numberrelated constraints, will not be tempted to apply unorthodox methods to place the aforementioned indicators between certain values (Nişulescu and Popescu, 2013).

Whatever the vision that we have on corruption, one of the most powerful tools in fighting this phenomenon is to inform and increase people's awareness about the disastrous consequences corruption may have over the general wealth and life standard.

\section{Methodology}

The purpose of this research is to support potential local or foreign investors having business operations in Romania and intending to also develop activity over the American continent. It is intended to achieve a quick and easy to interpret tool, which should be able to provide investors an overview of the social and economic environment of the concerned countries, so as the investors may act wittingly based on each surveyed country's profile and tolerance for corruption. The scientific demarche implies the literal sketching of a map of the American continent from the perspective of the corruption level and extension.

There are multiple entities studying corruption at the macroeconomic level, but one of the most prominent 
and internationally recognized organizations is Transparency International, which performs yearly charts of all the countries in the world, based on the perceived general level of corruption. Hereby, Transparency International is an information provider, providing rankings of all world countries according to their scores. Such a ranking will be the dependent variable in this study, called "the perceived level of corruption", the other variables will be reported to. For the other four independent variables (the number of taxes and duties, the time resources, the taxation level and the Human Development Index - HDI), which will more or less correlate with the dependent variable, the used data sources will be United Nations Human Development Report and the Paying Taxes Report for 2014, developed by PricewaterhouseCoopers. In developing the current research, the 2014 reports were chosen, as they were the only sources providing detailed and complete information for each analyzed country, so as the correlations could be performed.

The paper assumes as a novelty the fact that the resulting country rankings and the resulting map will be built based on the estimated level of corruption, by means of the four aforementioned independent variables. The first two variables (the number of taxes and duties and the time resources - as number of hours) represent the bureaucratic component of a state which may encourage or discourage the access of a foreign investor on the local market. The two variables are generally in correlation, in that the greater the values of the first variable, the bigger the time resources required for the payment of all the taxes and duties for a year. The next variable, taxation level, which is also oriented on the economic area, like the previous two, refers to the percent of the profit an economic entity has to pay as taxes and duties. The last variable, the HDI, also enclose a social side, as it refers to the actual life standard and development perspectives of an individual, which may shape the person's behavior and contribution to the general level of corruption.

The working procedure for this research implies the use of statistical functions, correlation tools, as well as the Excel Data Analysis tool, which will return some coefficients expressed as percent so as to assess the degree of influence of each of the four dependent values over the dimensions of corruption as a phenomenon. By applying these percent values to each independent variable, followed by the summation of the values of all the four for each country, an ascending sorted chart will be obtained. From comparability reasons, Romania will be included in the 31-countries sample. Thereby, based on successive comparisons to the values recorded for our country, we will be able to perform a highly accurate assessment of the dimension of corruption spread in each of the 31 countries. Based on the average level of corruption for the whole sample, three zones will be delimited as follows:

- Zone one encloses the countries where corruption has significantly lower levels, when compared against the whole sample average;

- Zone two encloses the countries whose score is close to the whole sample average;

- Zone three will enclose the countries having corruption levels significantly higher than the computed sample average.

After obtaining these rankings divided into zones, a map will be built and subsequently commented and analyzed from different perspectives.

\section{Results and discussions}

As a result of the data collection process for the year 2014, a database was obtained, as synthesized in Table 1.

As a result of using the statistical tool over the analyzed population, a set of correlation coefficients were obtained. The squared values of the correlation coefficients resulted as percent values, computed for each dependent variable, are as follows:

- The number of taxes and duties: $8.78 \%$

- The time resources: $7.31 \%$

- The taxation level: $10.12 \%$

- HDI: $73.79 \%$.

The database allows us to identify a few countries which will enter zone three without any doubt, as their values for time resources and taxation level are significantly higher than the average. The first country that stands out is Brazil, where an investor has to spend 2,600 hours a year in order to pay all the taxes and duties.

Surprisingly, Brazil has only nine taxes and duties, which renders the average time spent in order to pay a tax or duty to become 280 hours, compared to the 5.12 hours 
in Romania. A significant time resource value is also noted in the case of Bolivia, requiring 1,025 hours in order to pay 42 taxes and duties. As comparison, we may focus on Nicaragua, which also has 42 taxes and duties, but a time resource cost five times smaller than Bolivia, with 207 hours.

Significant time resources are also recorded for Venezuela - 792 hours and Ecuador - 654 hours. None of the aforementioned countries gets more than 50 points in the Transparency International chart, paradoxically the higher score being recorded for Brazil -43 points, which sets this country at the same level as Romania, also having 43 points in the chart of corruption perceived level. At the opposite end of Brazil reside Bahamas, having a yearly time resource value of 58 hours, rendering a spend of 3.22 hours for the payment of a tax or duty, as Brazil was having a value of 280 hours for the same purpose. Second to Bahamas, and the only one also having recorded yearly average time resources under 100 hours is Saint Lucia - 97 hours for 32 taxes and duties, rendering an average of 3.03 hours to pay a tax or duty, while the value for Romania is 5.12 hours. Even if the yearly average tax and duty payment time resource for Romania is over 173 hours under the average of the whole sample, our country is surpassed by the sample average with over 10 taxes and duties.

\begin{tabular}{|c|c|c|c|c|c|c|}
\hline Countries & $\begin{array}{l}\text { Perception of the } \\
\text { corruption level }\end{array}$ & $\begin{array}{c}\text { Number of } \\
\text { taxes }\end{array}$ & $\begin{array}{c}\text { Time } \\
\text { resources }\end{array}$ & $\operatorname{Tax}(\%)$ & $\mathrm{HDI}$ & Ranking \\
\hline Antigua and Barbuda & 74 & 57 & 207 & 41 & 0.783 & 24.86 \\
\hline Argentina & 34 & 9 & 405 & 107.8 & 0.836 & 41.92 \\
\hline Bahamas & 71 & 18 & 58 & 46.6 & 0.79 & 11.12 \\
\hline Barbados & 74 & 28 & 237 & 40.8 & 0.785 & 24.49 \\
\hline Belize & 52 & 29 & 147 & 33.2 & 0.715 & 17.18 \\
\hline Bolivia & 35 & 42 & 1,025 & 83.4 & 0.662 & 87.54 \\
\hline Brazil & 43 & 9 & 2,600 & 68.3 & 0.755 & 198.32 \\
\hline Canada & 81 & 8 & 131 & 24.3 & 0.913 & 13.41 \\
\hline Chile & 73 & 7 & 291 & 27.7 & 0.832 & 25.3 \\
\hline Columbia & 37 & 10 & 203 & 76 & 0.720 & 23.94 \\
\hline Costa Rica & 54 & 22 & 226 & 63.8 & 0.766 & 25.47 \\
\hline Ecuador & 33 & 8 & 654 & 33.9 & 0.732 & 52.48 \\
\hline El Salvador & 39 & 53 & 320 & 38.1 & 0.666 & 52.39 \\
\hline Grenada & 63 & 30 & 140 & 45.3 & 0.750 & 18.01 \\
\hline Guatemala & 32 & 7 & 326 & 40.9 & 0.627 & 29.05 \\
\hline Guyana & 30 & 35 & 256 & 32.5 & 0.636 & 25.54 \\
\hline Haiti & 19 & 47 & 184 & 40.4 & 0.483 & 22.02 \\
\hline Honduras & 29 & 47 & 224 & 39.2 & 0.606 & 24.92 \\
\hline Jamaica & 38 & 36 & 368 & 44.3 & 0.719 & 35.08 \\
\hline Mexico & 35 & 6 & 334 & 53.7 & 0.756 & 30.93 \\
\hline Nicaragua & 28 & 42 & 207 & 64.9 & 0.631 & 25.85 \\
\hline Panama & 37 & 52 & 417 & 40.5 & 0.780 & 39.72 \\
\hline Paraguay & 24 & 28 & 384 & 35 & 0.679 & 34.57 \\
\hline Peru & 38 & 9 & 293 & 36.4 & 0.734 & 26.43 \\
\hline Dominican Republic & 32 & 9 & 324 & 43.5 & 0.715 & 29.4 \\
\hline Saint Lucia & 67 & 32 & 97 & 34.6 & 0.729 & 13.94 \\
\hline USA & 74 & 11 & 175 & 46.3 & 0.915 & 19.12 \\
\hline Suriname & 36 & 29 & 199 & 27.9 & 0.714 & 20.44 \\
\hline Trinidad and Tobago & 38 & 39 & 210 & 29.1 & 0.772 & 22.29 \\
\hline Uruguay & 73 & 33 & 310 & 41.9 & 0.793 & 30.58 \\
\hline Venezuela & 19 & 71 & 792 & 61.7 & 0.762 & 70.94 \\
\hline Romania & 43 & 39 & 200 & 42.9 & 0.793 & 32.97 \\
\hline
\end{tabular}

Source: Authors' compilation, 2016 
A front place is taken by Venezuela, having 71 taxes and duties, the highest value for the whole sample, followed by Antigua and Barbuda - 57 taxes and El Salvador -53 taxes. Perfect equality and values high above the average a recorded for Haiti and Honduras, having 47 taxes and duties each. The lowest value belongs to Mexico -6 taxes and duties, followed by Guatemala and Chile with 7 taxes and duties each. Even if the figures for Guatemala and Chile are quite the same, and the yearly time resource are around 43 hours, the Transparency International chart reveals a large gap in the perceived level of corruption for the two countries, where Guatemala scores 32 points, while Chile scores 73 . This can be explained by the fact that it is not the bureaucratic components who generate the gap, but the taxation level, which is much larger in Guatemala, and the Human Development Index, which is a lot greater for Chile. Regarding taxation, a quite unusual situation may be observed in Argentina, where the taxation level is $107.8 \%$. In other words, in order to achieve a profit of 100 monetary units, an economic entity has to pay $29.4 \%$ as work-related taxes, $3 \%$ as direct taxation of profit, and another $75 \%$ with different profit-related taxes and duties. High taxation levels are also obvious for Brazil - $83.4 \%$ and Bolivia - $68.3 \%$, while the lowest levels are observed in the case of Canada $-24.3 \%$ and Chile $-27.7 \%$. The last variable, the Human Development Index (HDI) depicts the life standard of the people and is an important parameter for measuring corruption. Countries with the highest HDI values reside in North America - USA - 0.915 and Canada - 0.913, followed by two Latin American countries - Argentina -0.836 and Chile - 0.832. Even if the average for the whole sample is 0.734 , Romania has a significantly higher value -0.793 .

After applying the percentages to the four dependent variables (the number of taxes and duties, yearly time resources, taxation level and $\mathrm{HDI}$ ), the result was a series of scores, or rankings, which were used to assign each country to a certain "zone", as depicted in Table 2.

Table 2. Countries rankings and zones according to the estimated level of corruption

\begin{tabular}{|l|l|l|l|l|l|l|l|l|}
\hline \multicolumn{1}{|c|}{ Country } & Ranking & Zone & \multicolumn{1}{c|}{ Country } & Ranking & Zone & \multicolumn{1}{c|}{ Country } & Ranking & Zone \\
\hline Bahamas & 11,12 & 1 & Chile & 25,3 & 2 & Jamaica & 35,08 & 3 \\
\hline Canada & 13,41 & 1 & Costa Rica & 25,47 & 2 & Panama & 39,72 & 3 \\
\hline St Lucia & 13,94 & 1 & Guyana & 25,54 & 2 & Argentina & 41,92 & 3 \\
\hline Belize & 17,18 & 1 & Nicaragua & 25,85 & 2 & Ecuador & 52,48 & 3 \\
\hline Grenada & 18,01 & 1 & Peru & 26,43 & 2 & Venezuela & 70,94 & 3 \\
\hline USA & 19,12 & 1 & Guatemala & 29,05 & 2 & Bolivia & 87,54 & 3 \\
\hline Suriname & 20,44 & 1 & Dom. Republic & 29,4 & 2 & Brazil & 198,32 & 3 \\
\hline Haiti & 22,02 & 1 & Uruguay & 30,38 & 2 & & & \\
\hline Trinidad \& Tobago & 22,29 & 1 & Mexico & 30,93 & 2 & & & \\
\hline Romania & 22,97 & 1 & El Salvador & 32,39 & 2 & & & \\
\hline Columbia & 23,94 & 1 & Paraguay & 34,57 & 2 & & & \\
\hline Barbados & 24,49 & 1 & & & & & & \\
\hline Antigua \& Barbuda & 24,86 & 1 & & & & & & \\
\hline Honduras & 24,92 & 1 & & & & & \\
\hline
\end{tabular}

Source: Authors, 2016

In order to properly establish the three zones, the ranking of Brazil was eliminated, as it was significantly biasing the general average, and the reference value was 29.73 points. Oscillations were permitted around this value, in a general marge of $+/-5$ points. Therefore, for the Zone 2, the interval was set between 25.3 points (Chile) and 34.57 points (Paraguay). The countries scoring less than 25.3 points were enclosed in Zone 1 , while countries scoring more than 34.57 points were enclosed in Zone 3.
In the "estimated level of corruption" chart, the first place belongs to Bahamas which has the best score -11.12 points, followed by Canada with 13.41 points and Saint Lucia with 13.94 points. The three aforementioned countries were noticed as having strong positive situations since the build of the database, as Bahamas and Santa Lucia were the only countries with yearly time resources 
less than 100 hours for the payment of all the taxes and duties. Canada registered very good scores for the total number of taxes and duties, and also a very good $\mathrm{HDI}$ value. As compared against the sample average of 35.58 points, Romania scores 22.97 points, which places the country in Zone 1, together with Trinidad \& Tobago, Haiti and Suriname. The lowest score from Zone 1 belongs to Honduras - 24.92 points, while the amplitude of Zone 1 is 13.8 points.

Concerning the Zone 2 (the zone having values close to the average of the sample), the first position belongs to Chile -25.3 points and the last position belongs to Paraguay -34.57 points, which renders an amplitude of Zone $238.83 \%$ lower than the amplitude of Zone 1. Zone 3 encloses the countries with the highest perceived levels of corruption, and also has the highest score variations from country to country. Therefore we can observe the lowest score in Jamaica - 35.08 points and the highest one in Brazil - 198.32 points. Brazil manages to establish the third consecutive record when compared against the other countries enclosed in the analysis. Since the beginning Brazil stood out with a very high number of hours for the yearly time resource -2600 , which rendered an average duration of 288 hours necessary for the payment of a tax, and now it is the only country scoring more than 100 points, a value 5.6 times higher than the average. When comparing with our country, it can be said that while Bahamas's score is just two times lower than Romania's, the score of Brazil is more than 8.63 times higher than our country's. The interesting fact is that, even if it is placed last, Brazil has a number of taxes and duties two times lower than Bahamas and 4.33 times lower than Romania.

Based on the performed analyses and the established rankings, according to the depicted methodology, a corruption map will be built. The map is meant to suggestively and easily present the whole scientific work. The map which encloses the countries of the American continent is depicted in Figure 1, and each country is marked with a 1, 2 or 3 , according to the zone where is enclosed, based on the estimated level of corruption.

\section{Figure 1. Corruption Map for the American Continent}

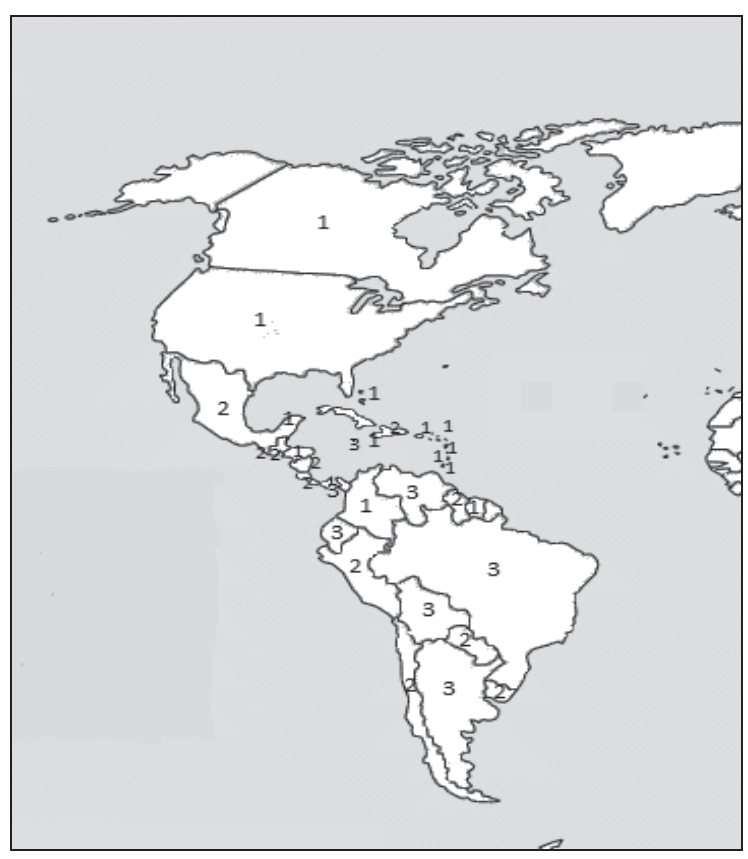

Source: Authors, 2016

As a short conclusion we can state that in the northern and central parts of the American continent, corruption is at very low levels, while in Central and South America there is an increase becoming more and more pronounced as we advance south. Latin America has the highest levels of corruption, the Zone 3 countries prevailing in this area. Looking at the map as a whole, a certain correlation may be noticed between the economic potential of a country and the corresponding level of corruption, and this is the reason a very thorough research will be performed from this perspective, so as to establish the real level of influence economic potential has over the corruption level. The correlation between the two may prove to be correct even at global level, not only for the American continent. The current investigation of the countries in America is part of a larger research regarding the worldwide levels of corruption and their correlations. The results obtained from America will be compared and correlated with results obtained on the other continents, so as the final result will be a world map of corruption level. 


\section{Ponclusions}

Corruption is a mass phenomenon which cannot be isolated between the borders of a country or even a continent, has a cross-border behavior, and based on the authorities' interests and efforts in the area, it may be kept at low levels or, on the contrary, it may develop to very high levels.

Even if corruption is an integral part of people's behavior, it may be increased or suppressed by some specific measures.

As this study reveals, the bureaucratic component of every state plays a central role in the spread of corruption as a phenomenon, and the usual explanation of the fact is that investors value their time very much and, by consequence, they choose to behave immorally by offering money, goods and other advantages to public workers in order to solve their problems as soon as possible. As proof for this hypothesis we have the fact that countries like Brazil and Bolivia which have the highest time resource cost for the payment of duties, also have the highest perceived levels of corruption from the surveyed countries.

Another component having a determinant role in the dimension of corruption is the Human Development Index, which reveals that people, apart from greed and the will to become rich rapidly, also recourse to corruption in order to ensure a decent life standard, or in some situations, even to survive. As proof of this theory are the two countries from North America, having the highest $\mathrm{HDI}$ values (0.915 and 0.913$)$, and both having top positions in Zone 1, which reveals very low levels of corruption.

Taxation level may influence corruption by the fact that people may choose to break the social rules not to survive or to save time, but also from pure greed. They consider it is more efficient to commit corruption acts and maximize profits, instead of working more or develop their business. Such countries, having a high taxation level are Argentina and Bolivia, both having some of the last positions of the chart, in Zone 3.

Following this scientific demarche, and also a study previously performed by Straupenhurst, Ulrich and
Strohal (2006) it can be confirmed that the economic potential of a country is correlated with the level of corruption in that country. According to the current study, the more developed the country, the lower the level of corruption (as in North America), and the poorer the country, the higher the corruption (as in Latin America).

Even if when the European Union is surveyed for corruption, Romania occupies one of the last places, when compared against American countries, it is situated in Zone 1. The reason may be that Romania recently cut the number of taxes and duties from 113 in 2012 down to 41 in 2013 and to 39 in 2014.

The current research also validates a study (Uslaner, 2008), which stated that countries having totalitarian regimes are more prone to high levels of corruption, when compared to democratic countries. It is obvious that in the countries where totalitarism is quite non-existent (like USA and Canada), the corruption level is low, while in the Latin America regimes are very restrictive and corruption flourishes.

The highest time resources allocated for the payment of taxes and duties are observed in Brazil and Bolivia, while the average duration on the American continent is twice as much as the average duration for Romania.

The average taxation level for the whole sample is 46.43 percent, which is $3.53 \%$ higher than the Romanian taxation level of 42.9 percent. An interesting case is the one of Argentina, having a taxation level of $107.8 \%$, which results in the fact that any company without external financial aid is unable to get profit, as the profit tax is only $3 \%$, while the other $104.8 \%$ are taxation of the work and various duties.

The lower level of corruption among the surveyed countries is Bahamas, with a general score of 11.12 points, while the highest level of corruption is found in Brazil, which has a score of 198.32 points.

In terms of the estimated corruption level score, Romania falls within Zone 1, ahead of countries such as Colombia, Barbados, Antigua and Barbuda, respectively Honduras. 


\section{REFERENCES}

1. European Commission (2014), Report from the Commission to the Council and the European Parliament. EU Anti-corruption Report [pdf] Available at: http://ec.europa.eu/dgs/homeaffairs/e-library/documents/policies/organizedcrime-and-human-trafficking/corruption/docs/acr_ 2014_en.pdf, [Accessed on 6 March 2016].

2. Jensen, N., Li, Q. and Rahman, A. (2010), Understanding corruption and firm responses in cross-national firm-level surveys, Journal of International Business Studies, vol. 41, pp.14811504, DOI: http://dx.doi.org/10.1057/jibs.2010.8.

3. Maxim, I. (2013), Globalizarea şi criminalitatea organizată, Revista de investigare a criminalității, vol. 4, nr. 1, pp. 261-267.

4. Morris, S.D. (2009), Political Corruption in Mexico: The Impact of Democratization. Boulder, CO, Lynne Rienner Publishers.

5. Nişulescu, I. and Popescu, L.M. (2013), Research on the financial engineering motivations and methods, and their implications on the information produced, In Accounting and Management Information Systems Conference Proceedings, pp. 1134-1147, Bucureşti.

6. Pană, E.C. and Nişulescu, I. (2013), Corruption with emphasis on health system, În volumul Analele Universității Ovidius, Seria Ştiințe Economice, vol. 13, no. 1, pp. 250-254, Constanța, Ovidius University Press.

7. PricewaterhouseCoopers (2014), Doing Business Report: Paying Taxes 2014, [pdf] Available at: https://www.pwc.com/gx/en/payingtaxes/assets/pwc-paying-taxes-2014.pdf, [Accessed on 6 February 2016].
8. Raicu, F. (2010), Corupția ca factor generator de insecuritate, Univers Strategic, vol. 5, no. 12, pp. 204-214.

9. Stapenhurst, R., Ulrich, M. and Strohal, S. (2006), Introduction: Parliamentarians fighting corruption, in R. Stapenhurst, În volumul N. Johnston and R. Pelizzo (editori), The role of parliament in curbing corruption. Washington, DC: The World Bank, pp. 1-12.

10. Transparency International Romania (2014), Evoluția indicelui de percepție a corupției în România şi în țările europene, [pdf] Available at: http://www.transparency.org.ro/politici_si_studii/indi ci/ipc/2014/CPI2014_RO_UE_Grafice.pdf, [Accessed on 6 March 2016].

11. Transparency International Romania (2014), Indicele de percepție a corupției, [online] Available at: http://www.transparency.org.ro/politici_ si_studi//indici/ipc/2014/CPI\%202014_Regional\%2 Owith\%20data\%20source\%20scores_RO.pdf, [Accessed on 6 February 2016].

12. United Nations Development Programme, Human Development Reports: Inequality-adjusted Human Development Index [online] Available at: http://hdr.undp.org/en/composite/lHDI, [Accessed on 6 February 2016].

13. Uslaner, E.M. (2008), Corruption, inequality, and the rule of law: The bulging pocket makes the easy life, New York: Cambridge University Press.

14. Voicu, A. (2013), Despre drept, morală şi religie, Revista de investigare a criminalității, vol. 4, no. 1 , pp. 40-45. 